\title{
THE POSITION OF FAMILIES IN THE NETHERLANDS
}

\begin{abstract}
This paper analyzes the situation of families in the Netherlands. Marriage and relationships are analyzed, i.e., the manner of concluding and breaking up, the necessary conditions, and the like. Parenting, the rights, and obligations that arise, as well as the general family structure of families in the Netherlands. To get a broader picture of the families in this country, a review of several indicators was made and the statistical indicators for marriages, divorces and live births from 1950 to 2017 were compared. The main assumption is that a liberal society provides better conditions for the development and advancement of families.
\end{abstract}

Keywords: family, marriage, divorce, parenting, Netherlands.

\section{Introduction}

Located in Western Europe, the Netherlands borders Belgium to the south, Germany to the east, and the North Sea to the north and west. The country has a total area of $41,526 \mathrm{~km}^{2}$. The population of the Netherlands includes members from many countries around the world. The population is largely Dutch, comprising $79.3 \%$ of the total population. They are the major ethnic group of the country. Other ethnics that are minorities here include: Europeans comprising $5.7 \%$ of the population, the Turks comprising 2.4\%, Indo-Europeans with $2.3 \%$ of the population, Moroccans at $2.2 \%$, Surinamese with $2.1 \%$, Caribbeans at $0.9 \%$, Chinese at $0.3 \%$ and some other ethnic groups that comprise the remaining 3.9\% (World Population Review). In 1951, the Netherlands became a member of the European Coal and Steel Community (along with five other countries), which is the forerunner of the European Union (Radulovic, 2015: 1). The Dutch have a religiously tolerant society. The difference of religions is accepted and evident throughout the country through various places of worship. In the Netherlands in 2015, 23,7\% of the population identify as Roman Catholic, $15,5 \%$ identify as Protestant, and 10,6\% identify with another religion. Half of the population $(50,1 \%)$ does not identify with any religion (World Population Review). The Netherlands has one of the best health systems in the world. It is also considered one of the most democratic countries in the world. When it comes to relationships and family formation, the people of the Netherlands are completely free to choose a partner and the form of the relationship. 


\section{Formalizing partnership}

Dating practices in the Netherlands are similar to those throughout Western Europe. During high school, teenagers will begin to socialize in group activities with peers from school or those living in the same neighborhood. The Dutch choose their partners out of love, arranged marriages are not a cultural custom and are disapproved (Scroope, 2017).

From the 1st of April 2001 homosexual and heterosexual couples wanting to formalize a relationship can choose between three options: civil marriage, registered partnership, or a cohabitation agreement. The last-mentioned only has legal consequences for the parties who have signed it and only covers those issues, which the parties themselves want it to cover. The cohabitation agreement has to be legally drawn up by a notary. Apart from these formalized relationships, more than 1.4 million couples are living together without any formalization of their relationship (Antokolskaia, Woelki). If two partners want to get married or enter into a partnership, they must follow the conditions: both partners must be at least 18 years, inform the municipality a maximum of 1 year and a minimum of 5 weeks before the date of the ceremony, not to be in another marriage or registered partnership, not to be related by blood. The marriage or partnership can be registered in any municipality in the Netherlands (DenHaag, 2021). Several municipalities in the Netherlands also have the possibility of a free wedding. However, this service is only possible at certain hours and days. In large Dutch cities, dates for free weddings or registered partnerships are often booked months in advance (Xpat.nl, 2018). In 2001, the Netherlands became the first country in the world to allow same-sex marriage.

There are three ways to end a marriage or a registered partnership: divorce, legal separation (the partners are still married but not living together), and divorce /end registered partnership after the legal separation. In the case of separation, the partners must enter into an agreement covering child support, joint pension, and other matters (Government of Netherlands).

\section{Family structure}

"Family" and "family life" are not limited to traditional concepts of the family. In addition to the traditional family of a man and a woman who are married and have children, the term "family" is used to describe other primary living arrangements in which the care and upbringing of children take place. For example, single-parent families, persons living together, unmarried, of two opposite sexes, or the same sex are considered families. Regardless of the composition of the people, as soon as there are children to be raised, the people are a "family" (Vlaardingerbroe, 1995:635).

For many Dutch people, the immediate family remains important to the individual throughout his or her life. The personal relationships that family members share and the support they receive from each other are highly valued. 
Support and solidarity, financially and emotionally, are usually directed at the closest relatives (parents, children, and siblings) (Marres and Robben, 2006). However, individuals value their relatives and extended family. The Dutch are often encouraged to be independent and self-sufficient. Young people tend to leave home at the age of 18 to pursue higher education or employment. However, due to the lack of housing and rising university costs, many people can continue living with their parents until they are married. Dutch couples have a neo-local model of residence, as couples are free to choose where they live (Scroope, 2017).

A study was conducted in the Netherlands where 10,000 families were studied in detail and the researchers concluded that Dutch family ties remain close. But the question arises whether the foundation of this family relationship is primarily economic. It reveals that 50 percent of children continue to live within a 10-kilometer radius of their parents when they are grown-ups. They take care of theirchildren and care for their parents as long as possible, in most cases only resorting to professional care when there is no other solution at hand. In previous decades, sociologists had declared the Dutch family dead. In the 1970s and 1980s, the family was portrayed as an outmoded, repressive, and primarily bourgeois organizational model.

Economically stable parents can allow their children to study longer. Once the children start work, they have less contact with their parents but when the grandchildren arrive, mum and dad are back in the loop again. "Grandparents are cheap and flexible babysitters. And what's more, they have plenty of time on their hands," explains researcher FreekBucx. In this phase, grown-up children see their parents at least once a week. A pivotal time in the life of a family is the moment that the children reach the age of 40, discovered researcher Eva Maria Merz. “Up to that point, parents support their children. Afterward, the children are the ones supporting their parents, eventually shouldering full responsibility for their care. In fact, this image of the renewed sense of family reflects the reality of a relatively small section of society (Tol).

\section{Parents, children, rights, and responsibilities}

Parents must take care of the child. This means that they must meet the basic needs of the child such as food, place of residence, and education. The parent is also the legal representative of the child and is responsible for his/ her behavior and life until he/she turns 21 years old. Dutch law defines when people are considered mother and father. Accordingly, the mother is: a woman who gave birth to the child, a woman who adopted the child, and a woman who recognized the child or was declared the parent of the child by the court. The father is: the husband of the mother or the registered partner at the time of the birth of the child unless his paternity of the child is denied, the man who has recognized or adopted the child, the man who has been declared the father of the child by the court (Government of Netherlands). 
The average family is relatively small, with only one or two children. The child receives a lot of parental attention. Because many families employ both parents, children aged 6 weeks and older are often placed in kindergarten when their parents are at work. Dutch childcare practices are lenient. Children are encouraged to discover their surroundings individually or with other children. Corporal punishment is not approved by most parents. Peer groups are important among Dutch adolescents. Teenagers have developed a wide range of subcultures to explore their identity (Mares and Robben, 2006).

\section{Right to maternity leave}

In the Netherlands, women are entitled to 16 weeksof paid maternity leave. Maternity leave can start 4-6 weeks before the baby's date of birth and lasts up to 10 weeks after the baby is born. If twins are expected, you can get an additional 4 weeks of maternity leave. It is legally permissible for a woman to return to work after completing a 6-week leave. During pregnancy, a woman is paid $100 \%$ of her normal salary. It can be paid by the employer or directly from the social security institution. If there is a premature birth of the child, the mother is still entitled to full paid leave. Also, if the child has to stay in the hospital for a longer period, the mother has the right to take a maximum of 10 weeks of maternity leave. The father is entitled to one week of unpaid leave after birth, and up to 6 months of unpaid leave. Another type of family leave in the Netherlands is parental leave (Xpat.nk, 2018). Starting July 1, 2020, fathers, as well as same-sex couples, will receive 5 weeks of paternity leave in the first 6 months after the baby is born. For a period of 5 weeks, the partner will receive 70 percent of their salaries (Humaninprogres.com, 2020).

\section{Parental responsibility in the event of a divorce or termination of a registered partnership}

In the event of a divorce or termination of a registered partnership, both parents remain responsible for the care and upbringing of the children. If one of them waives the obligation, he should submit a request to the court, which ultimately decides on the final decision. If there is more than one child in the marriage or registered community, the court will assign parental responsibility for each child independently. From the age of 12, the child can ask the court to transfer the responsibility to a certain parent. The custodial parent has to support the child until his or her 21st birthday. The court should ask children aged 12 and over to give their opinion when parental liability is granted. There is no such requirement for younger children. The child has the right to be heard and is therefore given the opportunity to tell the court what he or she thinks about certain issues relating to the breakup (Government of Netherlands). 


\section{Adoption}

In 1993, the Netherlands was one of the first 66 countries to sign the Hague Accession Convention, which now counts 81 countries. All Member States are either the country of origin of the child or countries where the prospective parents live. Everyone agreed with the rules regarding adoption, and everyone focused on the best interests of the child. The process of adopting a child can take from three to five years. The process will bring potential parents in contact with the Child Protection Board, the Central Authority of the Ministry of Security and Justice, and intermediary organizations. This includes the application process, the home study, and the necessary assessments to find the best parents for each child. There are numerous rules and regulations for international adoptions (Adopti.nl, 2018). Anyone wishing to adopt a child from the Netherlands must meet several conditions. The adopter must be at least 18 years older than the adoptive child. When it comes to adopting a child from same-sex or different-sex partners, couples must live together for at least 3 years when starting the adoption process. They need to prove this with a cohabitation agreement or information from the personal records database. Marriage is not a condition for a couple to adopt a child. Also, the child can be adopted by his/ her parent's new partner only if the partner lives with the legal parent for at least 3 years when he/she starts the adoption procedure and has to take care of the child for at least 1 year. If the child is 12 years old or older, he must give his consent for his adoption (Government of Netherlands).

\section{Teams for children and parents}

When it comes to raising a family in Amsterdam, the parent-child team is a primary source of advice and guidance. More than 20 teams are working throughout the city, specializing in a range of parenting and parenting issues. Teams for parents and children cover a wide range of issues, including obstetrics, maternity care, child health care, and education. Examples of specialist advice and services include diet tips, parenting courses, and workshops on topics such as violence. Teams for parents and children also work with speech therapists and physiotherapists. The teams care for children of all ages, so the services provided are not limited to preschool children. Many of the provisions for those aged four and over are provided in collaboration with local schools (Iamsterdam, 2018). 


\section{Indicators related to families}

\section{Marriages concluded}

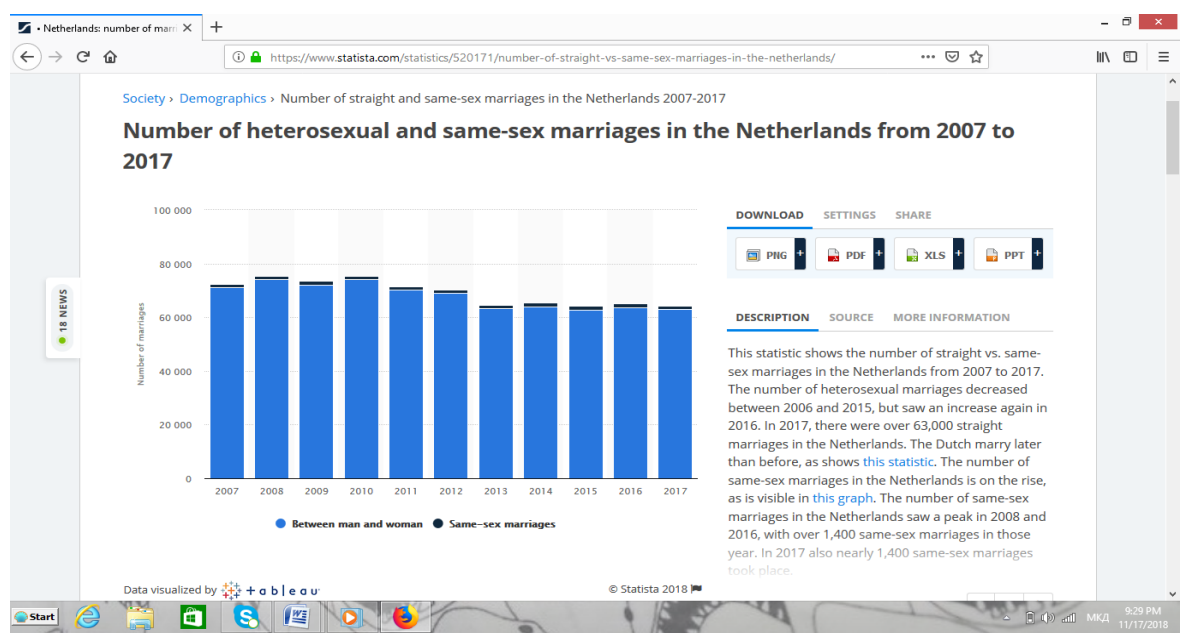

The number of marriages between a man and a woman is marked in blue, and the number of same-sex marriages is marked in black. (Statista, 2018)

The data from the graph show that in the period 2007-2017 there are no drastic variations in terms of the number of marriages in the Netherlands. In 2007, 72485 marriages were concluded, of which 71114 were between heterosexual couples and 1371 were between homosexual couples. There is an increase in 2008 and 2010 where 74030 heterosexual and 1048 homosexual marriages were concluded, i.e. a total of 75078 for 2008, and in 201074045 heterosexual and 1354 homosexual marriages were concluded, which results in a total number of 75399 concluded marriages. In 2017, a total of 64,402 marriages were concluded, of which 63027 were between heterosexual couples and 1375 between homosexual couples. 


\begin{tabular}{|c|c|c|c|c|c|c|c|c|c|c|c|}
\hline & & $\begin{array}{l}\text { Peri- } \\
\text { ods }\end{array}$ & 1950 & 1960 & 1970 & 1980 & 1990 & 2000 & 2015 & 2016 & 2017 \\
\hline \multirow[t]{5}{*}{$\begin{array}{l}\text { Mar- } \\
\text { riag- } \\
\text { es } \\
\end{array}$} & $\begin{array}{l}\text { Total } \\
\text { mar- } \\
\text { riages }\end{array}$ & $\begin{array}{l}\text { num- } \\
\text { ber }\end{array}$ & 83110 & 89100 & 123635 & 90182 & 95649 & 88074 & 64308 & 65249 & 64402 \\
\hline & $\begin{array}{l}\text { Mar- } \\
\text { riag- } \\
\text { es, } \\
\text { rela- } \\
\text { tive }\end{array}$ & $\begin{array}{l}\text { Per } \\
1000 \\
\text { in- } \\
\text { hab- } \\
\text { itants }\end{array}$ & 8.2 & 7.8 & 9.5 & 6.4 & 6.4 & 5.5 & 3.8 & 3.8 & 3.8 \\
\hline & $\begin{array}{l}\text { Be- } \\
\text { tween } \\
\text { man } \\
\text { and } \\
\text { wom- } \\
\text { an } \\
\end{array}$ & $\begin{array}{l}\text { num- } \\
\text { ber }\end{array}$ & 83100 & 89100 & 123631 & 90182 & 95649 & 88074 & 62912 & 63813 & 63027 \\
\hline & $\begin{array}{l}\text { Be- } \\
\text { tween } \\
\text { men }\end{array}$ & $\begin{array}{l}\text { num- } \\
\text { ber }\end{array}$ & & & & & & & 647 & 665 & 620 \\
\hline & $\begin{array}{l}\text { Be- } \\
\text { tween } \\
\text { wom- } \\
\text { en }\end{array}$ & $\begin{array}{l}\text { num- } \\
\text { ber }\end{array}$ & & & & & & & 749 & 771 & 755 \\
\hline
\end{tabular}

(Statista, 2018)

In the period 1950-2017, there is a greater variation in terms of the number of marriages. The rate of marriages in the Netherlands was highest in the 1970s, in the 1980s and 1990s it was the same and decreased compared to the 1970s, while in 2015, 2016, and 2017 it was the lowest at 3.8 marriages per 1000 inhabitants. 


\section{Divorced marriage}

\begin{tabular}{|l|l|l|l|l|l|l|l|l|l|}
\hline & period & 1950 & 1955 & 1960 & 1965 & 1970 & 1975 & 1980 & 1985 \\
\hline Divorces & number & 6462 & 5498 & 5672 & 6206 & 10317 & 20093 & 25735 & 34044 \\
\hline $\begin{array}{l}\text { Divorces } \\
\text { per 1000 } \\
\text { inhabitants }\end{array}$ & & 0.64 & 0.51 & 0.49 & 0.50 & 0.79 & 1.47 & 1.82 & 2.35 \\
\hline $\begin{array}{l}\text { Divorces } \\
\text { per 1000 } \\
\text { couples }\end{array}$ & 3.0 & 2.3 & 2.2 & 2.2 & 3.3 & 6.0 & 7.5 & 9.9 \\
\hline $\begin{array}{l}\text { Average } \\
\text { duration of } \\
\text { marriage } \\
\text { at divorce }\end{array}$ & year & 11.2 & 11.4 & 11.1 & 11.5 & 11.8 & 12.5 & 11.9 & 12.8 \\
\hline $\begin{array}{l}\text { Total } \\
\text { percentage } \\
\text { divorces }\end{array}$ & $\%$ &. &. &. &. &. & 19.3 & 24.0 & 32.2 \\
\hline $\begin{array}{l}\text { Average } \\
\text { age of } \\
\text { divorcing } \\
\text { men }\end{array}$ & year & 38.4 & 39.6 & 39.1 & 39.1 & 38.6 & 38.7 & 37.7 & 39.6 \\
\hline $\begin{array}{l}\text { Average } \\
\text { age of } \\
\text { divorcing } \\
\text { women }\end{array}$ & 35.6 & 36.8 & 36.0 & 36.0 & 35.6 & 36.0 & 35.1 & 36.5 \\
\hline
\end{tabular}




\begin{tabular}{|l|l|l|l|l|l|l|l|l|l|}
\hline & period & 1990 & 1995 & 2000 & 2005 & 2010 & 2015 & 2016 & 2017 \\
\hline Divorces & number & 28419 & 34170 & 34650 & 31905 & 32544 & 34232 & 33414 & 32768 \\
\hline $\begin{array}{l}\text { Divorces } \\
\text { per 1000 } \\
\text { inhabitants }\end{array}$ & & 1.90 & 2.21 & 2.18 & 1.95 & 1.96 & 2.02 & 1.96 & 1.91 \\
\hline $\begin{array}{l}\text { Divorces } \\
\text { per 1000 } \\
\text { couples }\end{array}$ & 8.1 & 9.7 & 9.8 & 9.1 & 9.5 & 10.1 & 9.9 & 9.7 \\
\hline $\begin{array}{l}\text { Average } \\
\text { duration of } \\
\text { marriage } \\
\text { at divorce }\end{array}$ & year & 12.7 & 12.2 & 12.9 & 13.8 & 14.4 & 14.8 & 15.0 & 15.1 \\
\hline $\begin{array}{l}\text { Total } \\
\text { percentage } \\
\text { divorces }\end{array}$ & $\%$ & 28.1 & 31.7 & 33.9 & 33.4 & 36.2 & 39.6 & 39.1 & 38.8 \\
\hline $\begin{array}{l}\text { Average } \\
\text { age of } \\
\text { divorcing } \\
\text { men }\end{array}$ & year & 40.1 & 40.4 & 41.9 & 43.7 & 45.6 & 46.9 & 47.3 & 47.4 \\
\hline $\begin{array}{l}\text { Average } \\
\text { age of } \\
\text { divorcing } \\
\text { women }\end{array}$ & 37.2 & 37.7 & 39.0 & 40.7 & 42.5 & 43.7 & 44.0 & 44.2 \\
\hline
\end{tabular}

(Statista, 2018)

The table shows that the number of divorces in the Netherlands is increasing significantly from year to year. In 1950 the number of divorces was 6462 and in 2017 it was 32768 divorces. The divorce rate in the Netherlands in 2017 was 1.91 per 1000 inhabitants. Compared to the Republic of Macedonia where in 2017 the divorce rate was 6.6 divorces per 1000 inhabitants (State Statistical Office). The average divorce rate in the EU for 2017 is 2.2 divorces per 1000 inhabitants (Eurostat). 


\section{Number of life born children}

\begin{tabular}{|c|c|c|c|c|c|c|c|}
\hline & $\begin{array}{l}\text { Total } \\
\text { live born } \\
\text { children }\end{array}$ & $\begin{array}{l}\text { Crude } \\
\text { birth } \\
\text { rate }\end{array}$ & $\begin{array}{l}\text { General } \\
\text { Fertility } \\
\text { Rate }\end{array}$ & $\begin{array}{l}\text { Total } \\
\text { live born } \\
\text { children }\end{array}$ & Boys & Girls & $\begin{array}{l}\text { Boys } \\
\text { per } \\
1000 \\
\text { girls }\end{array}$ \\
\hline Periods & number & $\begin{array}{l}\text { Per } \\
1000 \\
\text { inhabit- } \\
\text { ants }\end{array}$ & Per 1000 & number & $\begin{array}{l}\text { num- } \\
\text { ber }\end{array}$ & number & $\begin{array}{l}\text { Per } \\
1000 \\
\text { girls }\end{array}$ \\
\hline 1950 & 229718 & 22.7 & 90.5 & 229718 & $\begin{array}{l}118 \\
521\end{array}$ & 111197 & 1066 \\
\hline 1955 & 229222 & 21.3 & 88.5 & 219222 & $\begin{array}{l}117 \\
588\end{array}$ & 111624 & 1053 \\
\hline 1960 & 239128 & 20.8 & 89.0 & 239128 & $\begin{array}{l}122 \\
796\end{array}$ & 116332 & 1056 \\
\hline 1965 & 245216 & 19.9 & 84.1 & 245216 & $\begin{array}{l}126 \\
064\end{array}$ & 119152 & 1058 \\
\hline 1970 & 238912 & 18.3 & 77.0 & 238912 & $\begin{array}{l}122 \\
330\end{array}$ & 116582 & 1049 \\
\hline 1975 & 177816 & 13.0 & 53.6 & 177876 & 91090 & 86786 & 1050 \\
\hline 1980 & 181249 & 12.8 & 50.5 & 181294 & 92948 & 88346 & 1052 \\
\hline 1985 & 178136 & 12.3 & 46.6 & 178136 & 91027 & 87109 & 1045 \\
\hline 1990 & 197965 & 13.2 & 49.9 & 197965 & $\begin{array}{l}101 \\
561 \\
\end{array}$ & 96404 & 1053 \\
\hline 1995 & 190513 & 12.3 & 47.3 & 190513 & 97560 & 92953 & 1050 \\
\hline 2000 & 206619 & 13.0 & 52.4 & 206619 & $\begin{array}{l}105 \\
637\end{array}$ & 100982 & 1046 \\
\hline 2005 & 187910 & 11.5 & 48.0 & 187910 & 96338 & 91572 & 1052 \\
\hline 2010 & 184397 & 11.1 & 48.0 & 184397 & 94129 & 90268 & 1043 \\
\hline 2015 & 170510 & 10.1 & 45.4 & 170510 & 87427 & 83083 & 1052 \\
\hline 2016 & 172520 & 10.1 & 46.0 & 172520 & 88587 & 83933 & 1055 \\
\hline 2017 & 169836 & 9.9 & 45.2 & 169836 & 87159 & 82677 & 1054 \\
\hline
\end{tabular}

(Statista, 2018)

Tables show that the number of live births decreases over the years in the Netherlands. The largest number of live births was recorded in 1950, with 229,718 live births. From this year, the number of live births begins to gradually decrease. In 2017, the number of live births was 169836 children and is the lowest number compared to previous years. The live birth rate for 2017 is 9.9 live births per 1000 inhabitants. Compared to the Republic of Macedonia where the live birth rate for 2017 is 10.5 (State Statistical Office). While the average rate of live births in the European Union in 2017 is 5.06 (Eurostat). 


\section{Conclusion}

The Netherlands, as a member of the European Union, seems to have made a great contribution to the creation of a liberal society. Family practices and activities help it to build a society in which the family is an important segment of people's lives. According to UNICEF, the happiest children are children living in the Netherlands due to the range of activities and benefits provided by the state such as child protection, family allowance, teams that serve to educate and solve family problems and needs (Today, 2017). The individualism and freedom provided by the laws of the state are a key part of the development of children and their actions as adults. The rate of lack of interest in religion contributes to Dutch society being free of interethnic tensions and conflicts. Acceptance of same-sex marriage is also an indicator of a lack of discrimination against this population. 


\section{References:}

Adoptie.nl. Adoptievoorzieningen. [online] Adoptievoorzieningenvorlichting, nazorgen consultative. Available at: https:/adoptie.nl/ [Accessed 18 Nov. 2018].

Antokolskaia, M and Woelki, K. Dutch family law in the $21^{\text {ST }}$ century: trend-setting and straggling behind at the same time.[pdf]. Available at: https://www.ejcl. org/64/art64-5.pdf [Accessed 28 May. 2021].

DenHaag, M. (2021). Register an intended marriage or registered partnership. [online] The Hague. Available at: https://www.denhaag.nl/en/marriage-andpartnership/register-an-intended-marriage-or-registered-partnership. htm [Accessed 28 May. 2021].

Europa.eu, (2018). Eurostatat . [online] Available at: https://ec.europa.eu/eurostat [Accessed 18 Nov. 2018].

Government.nl. Arranging a divorce, legal separation or termination of a registered partnership. [online] The Government of Netherlands. Available at: https:// www.government.nl/topics/divorce-separation-and-termination-ofregistered-partnership/divorce-legal-separation-or-termination-of-aregistered-partnership [Accessed 28 May. 2021].

Government.nl. Condition for adopting a Dutch child. [online] The Government of Netherlands. Available at: https://www.government.nl/topics/adoption/ adopting-a-dutch-child [Accessed 18 Nov. 2018].

Government.nl. Parental responsibility after divorce or termination of registered partnership. [online] The Government of Netherlands. Available at: https:// www.government.nl/topics/divorce-separation-and-termination-ofregistered-partnership/arrangements-concerning-the-children/parentalresponsibility-for-children-after-split-up [Accessed 18 Nov. 2018].

Government.nl. What are the legal rightsand duties of parents?.[online] The Government of Netherlands. Available at: https://www.government. $\mathrm{nl} /$ topics/family-law/question-and-answer/legal-rights-duties-parents [Accessed 18 Nov. 2018].

Humaninprogress.com, (2020). Paternity leave/Partner leave. [online] Available at:https://humaninprogress.com/expanded-parental-leave-netherlands/ [Accessed 28 May. 2021].

Iamsterdam.com. Parent and child center. Available at: https://www.iamsterdam. com/en/living/everyday-essentials/family-and-education/parent-andchild-centre [Accessed 18 Nov. 2018].

Mares, D and Robben, A. (2006). The Netherlands. [online] Everyday Culture. Available at: https://www.everyculture.com/Ma-Ni/The-Netherlands. html\#ixzz5WylqCeoO [Accessed 18 Nov. 2018].

Radulovic, M. (2015). Family in EU strategies (materials). Skopje: Faculty of Philosophy. 
Scroope, C. (2017). Dutch culture. [online] Culture Atlas. Available at: https:// culturalatlas.sbs.com.au/dutch-culture/dutch-culture-references\#dutchculture-references [Accessed 18 Nov. 2018].

Statista.com, (2018). Statista. [online] Available at: www.statista.com [Accessed 18 Nov. 2018].

Stat.gov.mk, (2018) State statistical office. [online] Available at: https://www.stat. gov.mk/ [Accessed 18 Nov. 2018].

Tol, M. Family life in Netherlands: strong and economic ties. [online] Expatica. Available at: https://www.expatica.com/nl/living/family/family-life-inthe-netherlands-103474/ [Accessed 18 Nov. 2018].

Today (2017). Dutch Children Deemed The Happiest In The World By UNICEF. [video]. Available at: https://www.youtube.com/watch?v=HUzxzf2UDfE [Accessed 18 Nov. 2018].

Vlaandingerbroeg, P. (1995). Marriage, Divorce, and Living Arrangements in the Netherlands. Family Law Quarterly, [online] Vol. 29, No.3, pp.635-644. Available at: https://www.jstor.org/stable/25740053?seq=1 [Accessed 28 May. 2021].

Worldpopulationreview.com, (2021). Netherlands population. [online] World Popilation Review. Available at: https://worldpopulationreview.com/ countries/netherlands-population [Accessed 28 May. 2021].

Xpat.nl, (2018). Getting merried in the Netherlands. [online] Available at: https:// www.xpat.nl/living-netherlands/family-matters/marriage/ [Accessed 18 Nov. 2018].

Xpat.nl, (2018). Mathernity leave in the netherlands. [online] Available at: https:// www.xpat.nl/living-netherlands/family-matters/maternity-leavenetherlands/ [Accessed 18 Nov. 2018]. 
